\title{
0-5 Yaş Çocuklarda Anemi Değerlendirmesi ve Ebenin Sorumlulukları
}

\section{Assesment of Anemia in Children 0-5 Years Old and Midwife's Responsibilities}

\author{
Elvan TUKEL ELMALI ${ }^{1}{ }^{1}$, Hale UYAR HAZAR ${ }^{2}{ }^{-}$ \\ ${ }^{1}$ İzmir İl Sağlık Müdürlüğü, Torbalı 12 No'lu Aile Sağlı̆̆ı Merkezi, İzmir, Türkiye \\ ${ }^{2}$ Aydın Adnan Menderes Üniversitesi Sağlık Bilimleri Fakültesi Ebelik Bölümü, Aydın, Türkiye
}

ÖZ

\begin{abstract}
Anemi, dünyada ve Türkiye'de sık görülen ve çocukları etkileyen önemli halk sağlığı sorunlarından biridir. Çocukluk çağında görülen en yaygın anemi nedeni ise demir eksikliğidir. Çocukluk döneminde anemi yaygınlığ gelişmiş ülkelerde \%4-20 arasında iken gelişmekte olan ülkelerde bu oran \%70-80'lere ulaşmaktadır. Anemi, küresel bir sorun olmakla birlikte özellikle gelişmekte olan ülkelerde son derece yaygındır. Tüm yaş grupları için yaşamsal önem taşıyan demir eksikliği anemisi, genel olarak 0-5 yaş grubu çocukların ortalama \%50'inde görülür. Ölümlerin yaklaşık yarısının 5 yaş altı çocuk grubunda görülmesinin altında yatan nedenlerden birisinin anemi olması konunun önemini daha da ortaya koymaktadır. Bu önemli halk sağlığı sorunun çözümü için Sağlı Bakanlığı ülke düzeyinde; toplumun demir eksikliği konusunda bilinçlendirilmesi, 4-12 ay arası bebeklere profilaktik amaçlı ücretsiz demir desteğinin sağlanması, anemisi olan 13-24 ay arası çocuklara demir tedavisinin önerilmesi amacıyla 2009 yılında “Demir Gibi Türkiye Projesi”ni başlattı. 0-5 yaş çocuklarda ayrıntılı sağlık öyküsü ve fiziksel değerlendirme yapılarak; aneminin tipi, neden olduğu semptomlar ve bu semptomların yaşamı nasıl etkilediği konusunda önemli veriler elde edilebilir. Anemi değerlendirmesi, çocuk izlemi yapan ebelerin de önemli sorumlulukları arasında yer alır. Sağlklı nesillerin yetiştirilmesi için anemi konusunda çocukların yeterli ebelik bakımı alması gerekmektedir. Sonuç olarak, aneminin değerlendirilmesi, önlenmesi ve tedavisinde ebelerin sorumluluk sahibi olmaları 0-5 yaş çocukların sağlı̆̆ının korunması ve geliştirilmesine katkı sağlayacaktır.
\end{abstract}

Anahtar Kelimeler: 0-5 yaş çocuk, Anemi, Ebelik bakımı.

\section{ABSTRACT}

Anemia is one of public health problems that are endemic in Turkey and the world and affect children. The cause of anemia that is common in childhood is iron deficiency. While anemia prevalence in childhood period is $4-20 \%$ in developed countries, this rate differs between $70-80 \%$ in develop in countries. As well as anemia is a global problem it is quite prevalent. Anemia of iron deficiency that is vital forallage groups is seen generally in fifty percent of 0-5 ages children. One of thereasons of half of the deaths are seen under 5 years children groups is anemia and this lay semphasis on this topic. Ministry of Health has started 'Turkey Like Iron Project' in 2009 for this important public health problem on the purpose of raising awareness of public about iron deficiency, providing free prophylactic iron support for each baby that is between 4-12 months, suggesting iron deficiency treatment for 13-24 months babies that have anemia. Important datas about type of anemia, causing symptoms and how these syptoms affecet life are acquired by making physical evaluation and detailed health history in 0-5 ages children. Anemia evaluation one of the important responsibility of midwives who make child following. Children must take enough midwifery care about anemia for growing healthy generation. Finally that midwivies have responsibility for evaluating, preventing and treatment of anemia can contribute to preventing and improving of 0-5 years children health.

Key Words: Anemia, Child in 0-5 years old, Midwifery care.

\section{GíRiş}

Anemi, geçerli referans aralığının altında bulunan kan hemoglobin veya hematokrit değeri şeklinde tanımlanır (1). Anemi sıklığı yaşa, cinsiyete, coğrafyaya, beslenme alışkanlıklarına ve sosyoekonomik duruma göre değişiklik gösterir. Demir eksikliği, çocukluk 
çağının en yaygın anemi nedenidir. Tüm sağlık çalışanları, anemi konusunda uyanık olmalı ve aileleri demir kaynakları konusunda bilinçlendirerek bu durumun giderilmesine çalışmalıdır (2).

Anemi, küresel bir sorundur ve özellikle gelişmekte olan ülkelerde son derece yaygındır. Çocukluk döneminde anemi yaygınlığg gelişmiş ülkelerde \%4-20 arasında iken gelişmekte olan ülkelerde bu oran \%70-80'lerde görülür (3). Dünya'da bebeklik ve çocukluk döneminde en sık görülen kan hastalığı, demir eksikliği anemisidir. Demir eksikliği anemisi sıklığının incelendiği araştırmalarda en düşük oran Kalifornia' da \%3.4 iken en yüksek oran Nijerya' da \%79.1'dir (4). Ülkemizde yapılan değişik çalışmalarda demir eksikliği anemisinin görülme sıklığ $\% 30$ ile \%78 arasındadır (5). İstanbul'da çocuk hastalıkları polikliniğine başvuran hastalarla yapılan çalışmada 2-6 yaş arası çocuklarda demir eksikliği anemisi sıklığı \%38.8'dir (6). Balıkesir ilinde 0-18 yaş arası 563 olguda yapılan bir araştırmada anemi prevalansı kızlarda \%15.09, erkeklerde \%34.2' dir (5). Tüm yaş grupları için yaşamsal önem taşıyan demir eksikliği anemisi, genel olarak 0-5 yaş grubundaki çocukların ve gebelerin ortalama \%50'sinde görülür (7). Çocukluk dönemde aneminin etkilerinin ağır olması nedeniyle, tarama programlarıyla aneminin takip edilmesi gerektiği ve tedavisinin desteklenmesi gerektiği belirtilmektedir. Özellikle iki yaş ve altı çocuklarda anemi; büyüme, gelişme ve bilişsel fonksiyonları önemli ölçüde etkiler. Bu nedenle aneminin erken tanı ve tedavisi çok önemlidir. Çalışmalara göre çocuklarda aneminin nedeni genellikle düşük sosyo-ekonomi ve beslenme ile ilgili sorunlardır (4).

Bir ülkenin geleceği ve umudu olan çocuklar, toplumun en kırılgan grubunu oluşturur. Bu nedenle en iyi koşullarda dünyaya gelmelerinin sağlanması, büyüme ve gelişmeleri için en uygun ortamın oluşturulması, geleceğe dönük fiziksel, ruhsal ve zihinsel donanımların sağlanması ülkenin geleceği açısından yaşamsal önem taşır. Sağlıklı nesillerin yetişmesi amacıyla sağlık hizmet sunumuna bütüncül ve kapsamlı olarak yaklaşmak gerekmektedir (8). Demir eksikliği anemisinin önlenmesinde; anemi prevalansının saptanması, beslenme eğitimi, demir desteği verilmesi, viral-bakteriyel-parazit hastalıkların kontrolü ve demirle besinlerin zenginleştirilmesi yer almaktadır (4). Sağlık Bakanlığı ülke düzeyinde; toplumun demir yetersizliği konusunda bilinçlendirilmesi, 4-12 ay arası bebeklere profilaktik amaçlı ücretsiz demir desteği sağlanması, anemisi olan 13-24 ay arası çocuklara demir tedavisinin önerilmesi amacıyla "Demir Gibi Türkiye Projesi”ni başlattı (7).

\section{Anemi Tanımı ve Prevalansı}

Eritrosit kitlesinde veya kan hemoglobin ve hematokrit konsantrasyonunda azalma veya hemoglobin değerlerinin o yaş ve cinsiyet için -2SD'den daha düşük olmasına anemi denir $(9,10)$. Dallman kriterlerine göre hematolojik parametreler Tablo 1'de gösterilmektedir (9).

Dünya Sağl1k Örgütü (DSÖ) tüm yaş dilimleri için anemiyi, hemoglobin değerinin kadınlarda $11.5 \mathrm{~g} / \mathrm{dL}$, erkeklerde $13 \mathrm{~g} / \mathrm{dL}$ 'nin altına düşmesi olarak tanımlanmaktadır (11) Sağlık Bakanlığı (2016)'na göre çocuklarda hemoglobin alt değeri $11 \mathrm{~m} / \mathrm{dL}$ ' dir (8). Her dört kişiden biri anemiden etkilenir. Özellikle gebe kadınlar ve okul öncesi çocuklar risk altındadır. Anemi prevalansı ile ilgili DSÖ’nün1993-2005 yılları arasında 192 ülkeyi kapsayan çalışmasında; dünyada 1.62 milyar insanda anemi olduğu belirtildi. Bu sayı dünya nüfusunun \%24.8'ini oluşturmaktadır. Bu araştırmaya göre okul öncesi ( $0-5$ yaş) anemi prevalansı \%47.4, 
okul çağında (5-15 yaş) \%25.4'tür. En yaygın prevalansı okul öncesi dönemdeki çocuklar, en düşük prevalansı ise erkekler oluşturmaktadır. Okul öncesi dönemde anemi prevalansı; Afrika'da \%64.6, Asya'da \%47.7, Avrupa'da \%16.7’dir (12).

Tablo 1. Dallman Kriterlerinde, Yaş ve Cinsiyete Göre Hematolojik Parametrelerin Ortalama ve Alt Sınırları, MCV (Ortalama Eritrosit Hacmi)

\begin{tabular}{|c|c|c|c|c|c|c|}
\hline & \multicolumn{2}{|c|}{ Hemoglobin (g/dL) } & \multicolumn{2}{|c|}{ Hematokrit (\%) } & \multicolumn{2}{|c|}{$\mathrm{MCV}(\mathrm{fL})$} \\
\hline Yaş & Ortalama & $-2 \mathrm{SD}$ & Ortalama & $-2 \mathrm{SD}$ & Ortalama & $-2 \mathrm{SD}$ \\
\hline $0,5-2$ & 12.5 & 11 & 37 & 33 & 77 & 70 \\
\hline $2-5$ & 12.5 & 11 & 38 & 34 & 79 & 73 \\
\hline $5-9$ & 13 & 11.5 & 39 & 35 & 81 & 75 \\
\hline 9-12 & 13.5 & 12 & 40 & 36 & 83 & 76 \\
\hline \multicolumn{7}{|l|}{$12-14$} \\
\hline $\mathrm{K}_{1 \mathrm{Z}}$ & 13.5 & 12 & 41 & 36 & 85 & 78 \\
\hline Erkek & 14 & 12.5 & 43 & 37 & 84 & 77 \\
\hline \multicolumn{7}{|l|}{ 14-18 } \\
\hline $\mathrm{K}_{1 \mathrm{Z}}$ & 14 & 12 & 41 & 36 & 87 & 79 \\
\hline Erkek & 15 & 13 & 46 & 38 & 86 & 78 \\
\hline
\end{tabular}

Sağlık İstatistikleri yıllığı (2017) verilerine göre, on beş yaş ve üzeri bireylerde hekim tarafından teşhis edilen anemi oranı erkelerde $\% 1.1$, kadınlarda $\% 9.5$ ve toplam nüfusta \%5.3'tür (8). Dünya Sağlık Örgütü verilerine göre Türkiye'de anemi prevalansının 2014 yılında \%27.7, 2015 yılında \%27.8, 2016 yılında \%28 olduğu ve giderek arttığı gözlenmektedir (13).

\section{Anemide Patogenez ve Etyoloji}

Eritrostlerin birincil fonksiyonu gaz değişimidir. Oksijeni akciğerlerden dokulara getiren ve karbondioksiti dokulardan akciğerlere getiren hemoglobini taşımak, eritrositlerin görevidir $(10,14)$.

Eritrositlerin yaşam süresi 120 gündür ve ortalama yüzde biri yaşam süreleri dolunca parçalanır. Hemolitik süreçlerde dolaşımdan uzaklaştırılan eritrositlerin oranı artar. Dolaşımdaki eritrositlerin mekanik, kimyasal, otoimmün ya da enfeksiyondan dolayı kısalan yaşam süreleri nedeniyle erken parçalanmalarına hemoliz denir. Eritrositlerin erken parçalanması durumunda kapasitesinden 7-8 kat fazla çalışan kemik iliği, hemolizi kompanse etmeye çalışır. Eritrosit yıkımının artmasıyla hemolitik anemi ortaya çıkar $(9,14)$.

Demir kanda transferrin olarak adlandırılan taşıyıcı protein ile birlikte taşınır ve daha çok hemoglobin şeklinde bulunur. En önemli işlevi vücudun oksijen taşıyan proteini olan "hem"in merkezinde geri dönüşümlü olarak oksijenin bağlanmasıdır. Hemoglobinin her bir ünitesi bir "hem" bağlar ve tetramer yapısında olması nedeniyle her bir hemoglobin ünitesi için + demir iyonuna ihtiyaç vardır. Demir eksikliği durumunda hemoglobin oluşumundaki son basamak ilerlemez ve yeterli miktarda "hem" yapılmaz. "Hem" eksikliği olduğunda otomatik olarak "hemeregulatedtranscriptional inhibitör (HRI)" etkisiyle "globin" biyosentezi baskılanır. Hem eksikliğinin sonucu olarak artan HRI aktivitesi bir yandan "globin" sentezini baskılarken, bir yandan da "hem" sentezindeki transkripsiyon başlatıcı anahtar faktörünün baskılanmasına sebep olur. Sonuçta "hem" ile birlikte "globin" sentezinin baskılanması sonucu demir eksikliği anemisi gelişir (14).

Hemolitik anemiler, eritrosit içi ve eritrosit dışı olmalarına göre iki gruba ayrılır. Eritrosit içi sebeplere bağlı anemilerin tamamı kalıtsaldır ve talasemi, orak hücreli anemi bu 
grupta yer alır. Eritrosit dışı sebeplere bağlı anemiler sonradan kazanılan hemolitik anemilerdir. Sonradan kazanılan hemolitik anemilerin etyolojisinde; immün sistem hastalıkları, enfeksiyonlar, ilaçlar ya da kan nakline karşı oluşan reaksiyonlar yer alır (1).

Süt çocukluğu, puberte, gebelik gibi büyümenin hızlı olduğu ve gereksinimin artmış olduğu durumlarda; demir, vitamin B12, folik asit eksikliği gibi besinsel eksiklikler anemilere sebep olabilir. Ancak vitamin B12 ve folik asit eksikliğine bağlı anemiler daha nadir görülmektedir. Bunun nedeni vitamin B12'nin uzun yıllar karaciğerde depolanabilmesidir. Folik asit ise hem hayvansal hem de bitkisel gidalarda bol miktarda bulunduğu için besinsel kaynaklı folat eksikliğine de sık rastlanmaz. Bu durumda en sık görülen anemi, demir eksikliği anemisidir ve günümüzde en çok ağırlık verilen anemi konumundadır (15). Demir eksikliği anemisinin diğer bir sebebi de kan kaybıdır. Sindirim sistemindeki peptik ülser, polip, hemanjiyom gibi lezyon veya özellikle çengelli solucan enfestasyonu kronik gizli kanamaya, ayrıca demir eksikliği de barsak mukozasını bozarak gizli kanamaya sebep olabilir (16).

\section{Aneminin Sınıflandırılması}

Anemilerde sınıflandırma, eritrosit morfolojisi ve patofizyolojisine göre iki şekilde olur.

I. Normositik Anemiler: MCH, MCHC normaldir. Akut kanama anemisi, hemolitik anemiler, kemik iliği yetersizliğidir.

II. Mikrositik Anemiler: $\mathrm{MCH}, \mathrm{MCHC}$ düşüktür. Demir eksikliği, sideroblastik anemiler, kurşun zehirlenmesi, kronik hastalıklar anemisidir.

III. Makrositik Anemiler: MCH artmıştır. Megaloblastik Anemiler (Vitamin B12, folik asit eksikliği) ve non-megaloblastik anemiler (myelodisplaziler, lösemiler, akut kanama anomalisi, hemolitik anemiler) olarak iki grupta toplanır (9).

Anemiler fizyopatolojik olarak eritrosit yapımının azalması, eritrosit yıkımının artması ve kan kaybı olmak üzere üç gruba ayrılır.

I. Eritrosit Yapımının Azalması: Hemoglobin sentezinde, DNA sentezinde bozukluk ve mekanizmaları tam bilinmeyen anemilerdir.

II. Eritrosit Yıkımının Artması: Hemolitik anemilerdir.

III. Kan Kaybı: Akut kanamalar, kronik kanamalardır (9).

\section{Demir}

Demir; oksijen taşınması ve depolanması, elektron taşınması, oksidatif metabolizma, hücre büyümesi ve çoğalmasında, esansiyel reaksiyonların katalizinde kullanılan, yaşam için vazgeçilmez bir elementtir. Enzimler ve proteinler tarafindan az ve önemli miktarlarda demir kullanılır (17).

Yaşamsal birçok biyolojik işlevde anahtar rol oynayan demir, eksikliği ve aşırı yüklenmesi durumunda önemli patolojilere yol açmaktadır. Demir homeostazisinin devamlılığının kontrolü; diyetle alınan demirin eritrositler tarafından emilimi, makrofajlar tarafından yeniden dolaşıma sunumu ve hepatositlerde depolanması ile sağlanmaktadır. Vücuttaki demirin düzeyi, yang1, enfeksiyon, anemi ve eritropoiezis aktivitesi tarafından düzenleyici rol oynayan ve karaciğer kökenli bir hormon olan hepsidin aracılığıyla kontrol edilmektedir $(14,18)$. 


\section{Demir Metabolizması}

Demir, taşınması ve depolanması sırasında daima iki oksidasyon durumu olan ferrik $(\mathrm{Fe}+3)$ ve ferröz $(\mathrm{Fe}+2)$ şeklinde bulunur. Demir hiçbir zaman serbest bırakılmaz, transferinle taşınır, ferritinde depolanır. Organizmada bulunan demirin \%60-70'i hemoglobinde ve dolaşan ertrositlerde, \%10'u miyoglobin ve sitokromlarda ve demir içeren enzimlerde yer alır. Retiküloendotelyal makrofajlar, yaşlanmış eritrositleri fagosite edip demiri yeniden kullanıma sunar. Yaklaşık 1 mg düzeyinde demir karaciğerde depolanır. Sonuç olarak demir, organizmada çok sıkı bir denetim altındadır. Günlük diyetle alınan demir duedenumdan emilir ve yine dışkı ile atılır. Organizmada demir atan fizyolojik bir mekanizma olmadığı için bu elementin sistemik dengesi tamamen emilim kontrolü ile sağlanmaktadır $(14,18)$.

\section{Demir Gereksinimi ve Temini}

Bir insanın günlük demir ihtiyacı 10-20 mg'dır. Bunun \%5-10'nu duodenum ve proksimal jejunumdan emilir. Barsak lümenindeki +3 değerlikli demir, +2 değerlikli demire çevrildikten sonra hücre içine alınır. Hücre içinde apoferritin ile birleşir ve ferritin olarak depo edilir. Demir eksikliğinde emilim \%20’ye kadar çıkabilir. Günde yaklaşık $1 \mathrm{mg}$ demir ter, idrar, gaita ve gastrointestinal sistemden dökülen hücreler ile kaybedilir (9). Diyette demir, "hem" demir ve et dışı kaynaklardan alınan "hem" olmayan demir olarak bulunmaktadır. "Hem" demir kırmızı ette bulunur ve emilim için gerekli olan duodenal düşük $\mathrm{pH}$ ve emilimi arttıran askorbik asit, sitrik asit gibi faktörlere gereksinim duymaz. Ferröz formdadır ve demir eksikliği olduğunda emilimi 2-3 kat artmaktadır. "Hem" olmayan demirin çoğu ferrik demir şeklinde olup, emilim için mide asiditesine gerek vardır (18).

\section{Demir Emilimini Etkileyen Faktörler}

Diyetteki demirin emilimi, asidik pH'da duodenumun proksimal kısmında ve ince barsakların yukarı kısmında gerçekleşir. Demir emilimini etkileyen faktörler; diyetteki toplam demir miktarı ve biçimi, demirin biyoyararlanımı, barsak mukoza hücrelerinden demir emiliminin kontrolü, kemik iliği eritropoetik etkinliği ve vücut depoları yani vücudun gereksinimidir. Vücutta depolanan demir miktarı azaldıkça veya eritropoez oranı arttıkça demirin emilimi artar (17).

Bebeklik döneminde tüketilen gıdalar içerisinde anne sütü, tek başına yeterli olduğu ilk 6 aylık dönemde, demir eksikliği anemisi açısından koruyucu olmaktadır. Anne sütünde bulunan laktoferrin adlı protein demir emilimini kolaylaştırmaktadır. $\mathrm{Bu}$ da anne sütündeki demirin biyoyararlılığını arttırmaktadır. İnek sütü yeterli demir içermekle birlikte, inek sütündeki demirin biyoyararlılığı anne sütüne göre düşüktür (15).

\section{Besinlerdeki Demirin Emilimini Etkileyen Faktörler}

Askorbik asit besinlerin mideden duodenuma geçiş sırasında demirin çözünmesini sağlar. Bunun için askorbik asitin yemekle birlikte alınması gerekir. Bazı fermente gıdalar diyetteki fitat miktarını azalttı̆̆ için demir emilimi artar. Örneğin, mayalı ekmek demir emilimini arttırırken, mayasız ekmek olarak bilinen lavaş veya yufka emilimi azaltır (19). Çay, kahve ve kakao demir emilimini \%40-60 azaltır. Kalsiyum, fosfor, magnezyum, teneke ve çinko +2 değerlikli olup Fe emilimini engeller (17). Alüminyum, paslanmaz çelik ve teneke de demir emilimini azaltır. Konserve kutusu açıldıktan sonra beklerken besin içinde teneke miktarı arttığından demir emilimi azalmaktadır (19). 
Demirin emiliminde, alınan besinin içeriği önemli olduğu için besinlerdeki demir, hem olan ve olmayan olmak üzere iki şekildedir. Hem olmayan demirin emilimini etkileyen faktörler ise olumlu ve olumsuz olmak üzere iki grupta ele alınmalıdır (Tablo 2).

Tablo 2. Hem Olmayan Demirin Emilimini Olumlu ve Olumsuz Etkileyen Faktörler

\begin{tabular}{|c|c|}
\hline $\begin{array}{c}\text { Hem olmayan demirin emilimini } \\
\text { olumlu etkileyen faktörler }\end{array}$ & $\begin{array}{c}\text { Hem olmayan demirin emilimini } \\
\text { olumsuz etkileyen faktörler }\end{array}$ \\
\hline $\begin{array}{l}\text { - Hidroklorik asit (mideden salgılanır) ve besinin } \\
\text { midede kalma süresi Fe emilimi arttırır (20). }\end{array}$ & $\begin{array}{l}\text { - Fitatlar (Tohumlar, tahil, baklagiller, çerezler vb) } \\
\text { Fe emilimini olumsuz etkiler }(19,20) \text {. Besinde } 50 \\
\text { mg fitat bulunması emilimi \%70 azaltır (19). } \\
\text { Sadece kepekte bulunan monoferrik fitat emilimi } \\
\text { etkilemez (24). }\end{array}$ \\
\hline $\begin{array}{l}\text { Askorbik asit (C vitamini) sebze ve meyvelerde } \\
\text { bol miktarda bulunur ve Fe emilimini arttır (20). }\end{array}$ & $\begin{array}{l}\text { - Polifenoller meşrubat ve bazı sebze meyvelerde } \\
\text { bulunur ve emilimi azaltır (21). }\end{array}$ \\
\hline $\begin{array}{l}\text { - Organik Asitler pirinç ağırlıklı yemeklerde ve } \\
\text { fermente gıdalarda bulunup Fe emilimini arttırır } \\
\text { (21). }\end{array}$ & $\begin{array}{l}\text { - Kalsiyum içeren süt ve süt ürünleri veya kalsiyum } \\
\text { tuzu özellikle yemekle birlikte alındığında Fe } \\
\text { emilimi azalır (25). }\end{array}$ \\
\hline $\begin{array}{l}\text { - Gasrik Asit hem olmayan Fe'nin emiliminde } \\
\text { gereklidir (20). Mide asidini pH'ı ile hem olmayan } \\
\text { demirin çözülmesi ve emilimi arasında zıt bir ilişki } \\
\text { vardır (22). }\end{array}$ & $\begin{array}{l}\text { - Yemeklerin yüksek ateşte pişirilmesi ve } \\
\text { yemeklerin sicak tutulması Fe emilimini azaltır } \\
\text { (17). }\end{array}$ \\
\hline $\begin{array}{l}\text { - Hayvansal dokularda hem demirin fazla } \\
\text { olmasının yanında hem olmayan Fe'nin emilimini } \\
\text { olumlu etkiler (23). }\end{array}$ & $\begin{array}{l}\text { - Posa invitro şartlarda emilimi azaltır. Selüloz ve } \\
\text { pektinler emilime olumsuz etki etmez, ispagula ve } \\
\text { psilium olumsuz etki eder (26). }\end{array}$ \\
\hline $\begin{array}{l}\text { - Açlık durumunda çözülebilir Fe tuzu alan kişilerin } \\
\text { Fe emiliminde artış olur (20). }\end{array}$ & $\begin{array}{l}\text { - Taninler arasında yer alan çay, kahve ve kakao } \\
\text { emilimi olumsuz etkiler }(17,19) \text {. }\end{array}$ \\
\hline
\end{tabular}

\section{Demir Eksikliği Evreleri ve Demir Eksikliği Anemisi}

Demir eksikliği (DE), vücuttaki demir depolarının boşalması anlamına gelir. Demir eksikliğine neden olan durum devam ettiğinde süreç Demir eksikliği anemisine (DEA) doğru ilerler. Demir eksikliği anemisi, yaşamı ve kalitesini olumsuz etkileyen bir sağlık sorunudur (27). Demir eksikliği vücutta prelatent dönem, latent dönem ve belirgin DEA olarak görülür. Prelatent dönemde, demir depoları azalmış veya yoktur. Serum demir yoğunluğu, hemoglobin ve hematokrit normaldir. Kemik iliği depo demirinde azalma veya yokluğun görülmesi ve serum ferritinin düşük olması ile bu evre tanınır. Latent dönemde, depo demirine ek olarak serum demiri (SD) ve transferritin satürasyonu azalmıştır. Hemoglobin ve hematokrit düzeyleri normaldir. Belirgin DEA'da depo demiri, serum demiri, transferrin satürasyonunun azalmasının yanı sıra hemoglobin ve hematokrit değerleri de azalmıştır (28).

\section{Demir Eksikliği Anemisinin Nedenleri}

Demir eksikliği, yetersiz demir alımı, demir emiliminde azalma, demir kaybında artış ve artmış demir ihtiyacı gibi sebeplerden kaynaklanmaktadır (Tablo 3) (1). 
Tablo 3. Demir Eksikliği Anemisinin Nedenleri

\begin{tabular}{ll}
\hline Yetersiz Demir Alımı & Demir Emiliminde Azalma \\
- Diyette yetersiz demir alınması & $\bullet$ Aklorhidri \\
& $\bullet \quad$ Gastrik rezeksiyon \\
& $\bullet \quad$ Çölyak hastalığı(glutenenteropatisi) \\
Demir Kaybında Artış & Artmış Demir İhtiyacı \\
- Gastrointestinal kanama & $\bullet \quad$ Süt çocukluğu \\
- Aşırı menstrual kanama & $\bullet \quad$ Gebelik \\
- Sik aralıklarla kan bağışı & $\bullet \quad$ Emzirme \\
- Gastrointestinal kanama & \\
- Aşırı menstrual kanama & \\
- Hemoglobinüri & \\
\hline
\end{tabular}

\section{Çocuklarda Demir Eksikliği Anemisi}

Sağlıklı term bebeklerde DEA, anne sütündeki demirin biyoyararlılığı etkisi ile dört aydan önce nadir görülürken diyetle demir almayanlarda yani anne sütü almayanlarda 6 aydan sonra görülme sıklığı artar (29). Bebek ve çocuklar, hızlı büyümelerinden dolayı yüksek demir gereksinimine ihtiyaç duyar. Bu nedenle demir eksikliği anemisi en çok bu dönemde görülür. Demir eksikliği anemisi kronik gastrointestinal kanal kanamaları, malabsorpsiyon ve beslenme yetersizliğinden kaynaklanmaktadır (30). Süt çocukluğunda demir eksikliği riskini arttıran durumlar Tablo 4'da belirtilmektedir (16).

Tablo 4. Süt çocuklarında demir eksikliği riskini arttıran durumlar

\begin{tabular}{ll}
\hline Artmış demir gereksinimi & Kan kaybı \\
\hline Düşük doğum ağırlığı & Plasental kanama \\
Hızlı büyüme & Beslenme hataları \\
Kronik hipoksi & İnek sütüne erken başlama \\
Doğumda düşük hemoglobin & Çay alımı \\
& Yetrersiz C vitamini alımı \\
& Altı aydan fazla sadece anne sütü alma \\
& Düşük sosyoekonomik durum \\
\hline
\end{tabular}

\section{Aneminin Değerlendirilmesi}

Anemide en sık görülen yakınmalar, halsizlik, baş dönmesi ve çarpıntıdır. Yüz, konjuktuvalar, oral mukozalar, tırnak yatakları ve avuç içi çizgilerinde solukluk aneminin belirtileridir. Bunun yanında solukluğu maskeleyebilen sarılık, siyanoz, kortikosteroid tedavisi, ırka bağlı pigmentasyon gibi durumların olabileceği unutulmamalıdır. Kalıtsal hemolitik anemilerde, solukluğun yanında göz aklarında sarılık, idrar renginde koyulaşma görülebilir (31). Ayrıca anemide, iştahsızlık, kilo kaybı, gece terlemesi, sık enfeksiyonlar, süt çocuklarında irritabilite, beslenme isteksizliği, kilo alamama, katılma nöbetleri görülebilir. Çocuklarda önemli bir bulgu da pikadır. Erişkin kişiler halsizlik, çarpıntı, çabuk yorulma, egzersiz ile artan sık nefes alıp verme, uykuya eğilim, başağrısı, baş dönmesi gibi nonspesifik yakınmalar bildirir $(15,16)$.

Anemili bir olguyu değerlendirirken, öykü ve fizik bakı aşamasında aneminin nedenini belirleyecek sorulara cevap aranmalıdır. Son zamanlarda veya o sırada açık bir kan kaybının olma durumu sorgulanmalıdır. Böbrek yetmezliği, kronik enfeksiyon hastalığı, kollojen vasküler hastalık gibi kronik bir hastalığın varlığı altta yatan nedenler hakkında bilgi verir. 
Adnan Menderes Üniversitesi Sağlık Bilimleri Fakültesi Dergisi 2020: 4(2); 171-182

Journal of Adnan Menderes University Health Sciences Faculty

Ailede solukluk, kan transfüzyon gereksinimi olan kişilerin veya anne baba arasında kan akrabalığının varlığı kalıtsal nedenlere götürür (15).

Tüm anemilerde tam kan sayımı yapılmalıdır. Bunun yanında basit biyokimyasal incelemeler ve akut hemolizle birlikte olan veya eritropoez yetersizliği olanlarda daha özgül laboratuvar incelemeleri yapilabilir (31).

Sağlık Bakanlığı, 1. Basamak Bebek, Çocuk Ergen İzlem Protokolleri’ne göre anemi değerlendirmesi

- 'Bebeğin 3-4 ay izlemlerinde; bebeği anemi yönünden değerlendirin. Anemisi varsa uygun yönergeleri kullanarak tedavi dozunda demir başlayın, anemisi yoksa 4. aydan itibaren uygun yönergeleri kullanarak proflaktik (+3 değerlikli demir için 4 damla/gün, +2 değerlikli demir için 9 damla/gün ve günde bir kez) dozda ücretsiz demir damlası verin.

- 6., 9., 12. ay izlemlerinde; demir kullanma durumunu sorgulayın. 9. ay izleminde bebeğin anemisini değerlendirmek amacıyla hemoglobin ve/veya hematokrit ölçümü yapın ve sonucu sisteme kaydedin.

- 4-6 yaş izlemlerinde; çocuğun anemisini değerlendirmek amacıyla hemoglobin ve/veya hematokrit ölçümü yapın ve sonucu sisteme kaydedin.

- Hemoglobin değeri $7 \mathrm{~g} / \mathrm{dL}$ veya hematokrit \%21 olan her bebek acilen hastaneye sevk edilmelidir (8).

\section{Anemiden Korunma ve Tedavi}

Demir eksikliği anemisinden korunmak için doğumdan sonra ilk altı ay sadece anne sütü özendirilmelidir. Doğumdan 6 ay sonra ise demir içeriği yüksek tamamlayıcı besinler başlanmalıdır. Sosyoekonomik durum ne olursa olsun, demir eksikliği anemisinin önlenmesi için, tüm çocukların büyüme ve gelişmeleri izlenmeli, aileler beslenme konusunda eğitilmeli, vitamin-mineral destekleri verilmeli ve erken tanı olanaklarından yararlanılmalıdır. Demir desteğine başlamak yeterli olmayıp, sürdürülmesi sağlanmalıdır (17). "Demir Gibi Türkiye" projesi kapsamında Sağlık Bakanlığı tarafindan, 4-12 ay arası her bebeğe profilaktik amaçlı ücretsiz demir desteği sağlanmakta ve anemisi devam eden 13-24 ay çocuklara da demir tedavisi önerilmektedir ve Sağlık Bakanlığı da bu emzirme politikasını desteklemektedir (7). "Demir gibi Türkiye" projesinin 2009 yılında sonuçlarına göre demir desteğine başlayan ailelerin oran $1 \% 95$, dördüncü ayda demir desteğine başlayan ailelerin oranı $\% 43.7$ 'dir. Proje kapsamında; demir desteği ile anemi görülme sıklığının azaldığı, aneminin,15 ayın altındaki çocuklarda daha fazla görüldüğü ve bu çocuklarda anemi tanısının, sağlık kontrolleri sırasında koyulmasına rağmen tedavilerinin yeterli ya da uygun yapılmadığının tespit edildiği belirtilmektedir (32).

En sık görülen demir eksikliği anemisinde tedavinin amacı anemiyi düzeltmek ve Fe depolarını doldurmaktır (9). Oral demir tedavisi etkili, güvenilir ve ucuz olduğu için ilk seçenektir. Oral demir tuzları ferröz ve ferrik olmak üzere iki formdadır. Demir tuzları asidik ortamda daha iyi emildikleri için askorbik asit ile alınmaları emilimini arttırır. Uygun bir demir tedavisiyle hemoglobin değerinin 3 haftada $2 \mathrm{~g} / \mathrm{dl}$ artması yeterli cevaptır. Hemoglobin değeri normale döndükten sonra depoların dolması için tedaviye 3-6 ay devam edilmelidir. Atrofik gastrit, gastrik cerrahi ve çölyak hastalığı gibi nedenlere bağlı emilim bozukluğu, oral demir 
tedavisine intolerans ya da uyumsuzluk, oral demir replasmanını aşan kronik kanamalar ve kronik hemodiyaliz durumlarının eşlik ettiği DEA'da parenteral demir tedavisi uygulanır (33).

Demir eksikliği anemisi tedavisinin önemli noktaları tedaviye uyum ve demiri düzenli kullanma, doz yetersizliği, kullanılan demir preparatının uygunluğu, demir kaybının veya kanamanın devam etmesi, tanının doğruluğu, demirin emilim ve vücutta kullanımını etkileyen (karaciğer hastalığı, böbrek hastalığı, tiroid yetmezliği, kurşun intoksikasyonu gibi) hastalık varlığı demir eksikliğine ek olarak vitamin $\mathrm{B}_{12}$ ve folik asit eksikliğinin bulunması, antasit gibi intestinal demir emilimini azaltan maddeleri alıp almadığı değerlendirilmelidir $(1,33)$.

\section{Aneminin Sonuçları}

Anemilerin çoğu yavaş geliştiği için eritrosit kaybı kompanse edilebilir. Bununla birlikte önemli kanamalar ya da çok hızlı hemoliz nedeniyle akut kan kaybı olan durumlarda vücuttaki kompanse edici mekanizmalar başarılı olmaz ve konjestif kalp yetmezliği gelişir (31).

Anemide temel fizyolojik bozukluk, kanın oksijen taşıma kapasitesinin azalması olduğu için hemoglobin değeri düzeyi düştükçe doku hipoksisi meydana gelir. Bunun sonucunda kas zayıflığı, dikkat süresinin kısalması, apati ve depresyon görülür. Hücre metabolizmasının azalmasına bağlı olarak çocuklarda cinsel gelişim gecikmesine sebep olur (31).

Demir eksikliği anemisinde iştahsızlığın bir sonucu olarak çocuklarda büyüme ve gelişme geri kalabilir. Demir eksikliği olan süt çocuğu ve çocukların boylarına göre düşük tartılı oldukları, demir ilavesi ile normale döndükleri bildirilmektedir. İmmün sistemde bozukluklar görülür ve enfeksiyonlara eğilim artar. Hızlı beyin büyümesiyle birlikte psikomotor becerilerin kazanıldığg süt çocukluğu döneminde demir eksikliği anemisi zeka düzeyinde kalıcı geriliğe sebep olabilir $(16,17)$. Çocukluk çağında katılma nöbetleri yaşayan olguların \%55,7'sinde DEA, \%17.2'sinde DE olduğu açıklandı. Anemi derinleştikçe katılma nöbetleri de artmaktadır. Anemi tedavisine başlanan çocuklarda katılma nöbetinde hızlı bir şekilde düşüş meydana gelir. Erken dönemde ise daha düşük dozlarda demir desteği alan hastalarda \%92 oranında nöbetler sonlanır (34).

\section{Anemide Ebelik Bakımı ve Ebenin Sorumlulukları}

Anemili hastaların bakım sürecinde hastanın ayrıntılı sağlık öyküsü ve fiziksel değerlendirilmesi yapılarak; aneminin tipi, neden olduğu semptomlar ve bunların hastanın yaşamını nasıl etkilediği konusunda önemli veriler toplanır (35).

Fiziksel değerlendirme: Anemi en kolay, kılcal dolaşımın çok melaninin az olduğu dudaklardan anlaşılabilir. Demir eksikliği anemisinde dil düz ve kırmızı, tırnaklar ince, kırılgan ve düzleşir ya da konkavlaşarak kaşık tırnak (koilonchia) şeklinde olabilir. Gastrointestinal sistem değerlendirmesinde bulant1-kusma, koyu renk gaita, ishal ve glosit (dilin enflamasyonu) gibi belirtilerin nedeni anlaşılabilir. Gaitada gizli kan yönünden değerlendirilir. Pernisiyoz anemi, merkezi ve periferal sinir sistemi etkilediği için nörolojik değerlendirme yapılmalıdır (35).

Öykü Alma: Öyküde, yakın zamanda açık bir kan kaybı olup olmadığı sorgulanmalıdır. Bunun yanı sıra süt çocukluğu döneminde gereksinim artışı ile ilişkili olarak beslenmeden kaynaklanan eksikliğe bağlı da anemi gelişebilir. Özellikle et tüketmeyenlerde demir eksikliği ve Vitamin B12 eksikliği, keçi sütü ile beslenenlerde folik asit eksikliğinin gelişmesi gibi. 
Deride solukluk ve göz aklarının sarı olması, öyküde hemolotik anemiyi düşündürmelidir. Ailede solukluk veya kan transfüzyonu gereksinimi olan kişiler ya da anne baba arasında akraba bağının olması, anemide kalıtsal nedenlerin varlığını ortaya koyabilir (15). Toksik maddelere maruziyete veya diğer hastalıkların semptom ve bulgularına bağlı da anemi belirtileri görülebilir (11).

Tedavi ve destekleyici bakım: Ciddi anemilerde oksijen tedavisi, eritrosit transfüzyonu ve dinlenme gibi destekleyici tıbbi bakım uygulanır (31). Oral demir tedavisi başlanan hastanın hemoglobin oranı 2-4 haftada 1-2 g/dL artacağı için tekrar hemoglobine bakılır. Anemi düzenlendikten sonra tedavinin fe depolarını doldurması için tedaviye 3 ay devam etmesi gerektiği açıklanır. Oral demir ilacı kullanımına tahammülsüzlük sık görülür. Böyle bir durumla karşılaşılırsa, ilaç 1-2 gün kesilmelidir. Sonra düşük dozdan başlanarak, hasta tolere ettikçe dozu arttırılarak 4-5 günde ideal doza çıkarılır (36). Oral tedaviye uyumsuzluk ve tahamülsüzlük, ağır anemiler, gastrointestinal hastalığın alevlenmesi, Fe emilimin bozuk olması, hemodiyaliz hastalığ 1 gibi durumlarda İntramüsküler (IM) veya İntravenöz (IV) tedavi yapılır. Parenteral tedavide hasta yan etkiler (hipoksi, ürtiker, ateş, bulantı, kusma, hipertansiyon, göğüs ağrısı, anafilaksi) açısından gözlenmelidir $(19,36)$.

Eğitim: Oral demir tedavisinde, ilaçların yan etkileri olan bulantı, kusma, dispepsi, konstipasyon, ishal, gaz, dışkının siyah renkli olması, dişlerin siyaha boyanması gibi konularda hasta ve ailesi bilgilendirilir. Dişlerin siyaha boyanmasını en aza indirgemek için, damla veya şurup formunun dilin arkasına doğru, dişlerle temas etmeyecek şekilde verilmesi; ilacın meyve suyu ya da su ile seyreltilerek verilmesi; ilacın bir pipet ile verilmesi önerilir (36). Oral alınan Fe preparatları veya Fe içerikli gıdalar ile emilimi olumsuz etkileyen gıdalar (süt ve ürünleri, çay, kahve, kakao vb) arasında iki saat ara bırakılmalıdır. İnek sütü günlük kullanımı 2 su bardağı ile sınırlandırılmalıdır (37).

Demir eksikliği anemisinin önlenmesi için; bebeklerin ilk altı ay anne sütü ile beslenmesi, altıncı aydan sonra anne sütü ile birlikte demirden ve $\mathrm{C}$ vitamininden zengin ek gıdaların verilmesi konusunda ailelere eğitim verilmelidir. Birinci basamak sağlık merkezlerinde ebe veya hemşireler tarafından yapılan izlemlerde bebek ve çocuklar anemi yönünden değerlendirilmelidir. Riskli görülen durumlar tespit edilip gerekli durumlarda sevk edilmelidir (8).

\section{SONUÇ}

0-5 yaş çocuklarda anemi, yaygın görülen ve çocukların yanında ailenin de hayatını olumsuz etkileyen önemli bir sağlık sorunudur. Anemi değerlendirmesinin belli aralıklarla yapılması aneminin erken fark edilmesini sağlayacaktır. Anemi değerlendirmesi, erken tanıda kullanılan önemli bir tanı aracıdır. Aneminin değerlendirilmesinde ve erken tanının koyulmasında ebenin sorumluluğu da büyük önem taşımaktadır. Aileler düzenli olarak sağlıklı çocuk kontrollerine gelmek istemeyebilirler ya da ihmal edebilirler. Ebenin bu kontrollerin yaptırılması için ailelere teşvik edici olması ihmali önleyecektir. Ebelerin çocuklarda anemiden korunma ve erken tanı konusunda hizmet içi eğitim planlamaları ve eğitim materyalleri geliştirerek toplumu bilgilendirmeleri gerekmektedir. Ayrıca ebeler, çocuklarda anemiyle mücadeleyi arttırmak, beslenmeyi düzenlemek ve tedavinin etkinliğini sağlamak için, onların yaşadığı deneyimleri ele almalı ve yaşadıkları olumsuzlukların giderilmesi konusunda yöntem 
ve stratejiler geliştirmelidirler. Böylece ebeler çocuk sağlığının korunması ve geliştirilmesine katkı oluşturabilirler.

\section{KAYNAKLAR}

1. William, F. K. (2002). $P D Q$ hematoloji, Ferhanoğlu B. İstanbul: İstanbul Medikal Yayıncilik

2. Yıldız, İ. (2009). Demir Eksikliği Anemisi. Türk Pediatri Arşivi

3. Sirdah, M. M., Yaghi, A., \& Yaghi, A. R. (2014). Iron deficiency anemia among kinder garten children living in them arginalize dare as of Gaza Strip, Palestine. RevBrasHematolHemoter, 36(2), 132-138

4. Kurt, A. S., Savaşer, S. (2010) Çocuklarda Demir Eksikliği Anemisinin Sıklı̆̆ı, Nedenleri ve Korunma Yolları: Literatür Taraması, Dokuz Eylül Üniversitesi Hemşirelik Fakültesi Elektronik Dergisi (DEUHYO ED) 3(s4): 201-208. http://acikerisim.deu.edu.tr/xmlui/bitstream/handle/12345/4572/201208_pdf.pdf? seque $\underline{\text { nce }=1 \& \text { is Allowed }=y}$ (Erişim Tarihi: 22 Aralık 2017)

5. Yazıcı, S., Çelik, T., \& Seyrek, K. (2012). Çocukluk çağında anemi sıklığı. İzmir Dr Behçet Uz Çocuk Hastanesi Dergisi, 2(1), 6-9

6. Bahar, A., Karademir, F., Aral, Y. Z., Göçmen, İ., \& Gültepe, M. (2003) Çocuklarda Demir Eksikliğinin Tespitinde Serum Demiri ve Eritrosit Çinko Protoporfin/hem Oranının Yeri, Çocuk Sağlığı ve Hastalıkları Dergisi 46: 24-29

7. Sağlık Bakanlığı, Ana Çocuk Sağlığı ve Aile Planlaması Genel Müdürlüğü, Demir Gibi Türkiye Projesi Genelgesi, 19 Şubat2004, sayı B100AÇS0140000 https://www.saglik.gov.tr/TR,11068/demir-gibi-turkiye-projesi--genelgesi-2004-21.html) (Erişim Tarihi:23 Ekim 2017)

8. Sağlık Bakanlığı. Bebek Çocuk Ergen İzlem Protokolleri 2016 http://ihs.istanbulsaglik.gov.tr/data/content/cekush_dosyalar/12\%20bebek_cocuk_erge n_izlem_protokolleri.pdf) (Erişim Tarihi:11 Ekim 2017)

9. Akalın, E., \& Güler, N. (1989) Hematoloji. ÖF Saraçoğlu (Ed.) Temel ve klinik bilimler (466-476). Ankara: Güneş Medikal Yayınevi

10. Guyton, A. C., \& Hall, J. H. (2007). Tibbi fizyoloji. H Çavuşoğlu \& B Çağlayan Yeğen (Çev Ed) (419-420) İstanbul: Nobel Tip Kitabevleri

11. Bozdemir, N., \& Kara, İ. H. (2010). Birinci basamakta tanı ve tedavi. Adana: Nobel Kitabevi

12. World Health Organzation. World prevalance of anaemia 1993-2005: Who global database on anaemia 2008. https://www.cabdirect.org/cabdirect/abstract/20093013528 (Erişim Tarihi:15 Kasım 2017)

13. World Health Organization. Anemia children 2017 http://apps.who.int/gho/data/node.main.ANEMIACHILDREN?lang=en (Erişim Tarihi: 21 Aralik 2017)

14. Yenerel, M. N. (2009). Anemi fizyopatolojisi. Klinik Gelişim Dergisi, 1(3) ,65-70.

15. Kavaklı, K., Castello, B., \& Aydınok, Y. (2005). Kan hastalıkları. S Kavukçu (Ed). Olgu sunumları ile çocuk hastalıkları (558-597) İzmir: İzmir Güven Kitabevi.

16. Neyzi, O., \& Ertuğrul, T. (2002). Pediatri. İzmir: Nobel Tıp Kitabevleri.

17. Bülbül, S. (2004). Çocuk beslenmesinde demirin yeri ve önemi. Sted, 13(12), 446-450

18. Uysal, Z. (Ekim 2010). Hepsidin ve demir metabolizması. VI. Hematoloji İlk Basamak Kursu, Ankara, s:9.

19. Yurdakök, K., \& İnce, O. T. (2009) Çocuklarda demir eksikliği anemisini önleme yaklaşımları. Çocuk Sağlığı ve Hastalıkları Dergisi, (52); 224-231. 
20. Lynch S. R. (1997). Interactionof iron with other nutrient. Nutr Rev., 55(4), 12-110

21. Gillooly, M., Bothwell, T. H., Torrance, J. D., MacPhail, A. P., Derman, D. P., Bezwoda, W. R. Et all. (1983). The effects of organic acids, phytates and polyphenolson the absorption of iron vegetables. Br J Nutr., (49):331-342.

22. Bezwoda, W., Charton, R., Bothwell Torrance, J., \& Mayet, F. (1978). The importance of gastric hydrochloric acid-in the absorption of nonheme food iron. J Lab Clin Med, $1(1), 108-116$.

23. Knee, A. P., \& Miller, D. D. (1984). In vitro Estimation of the Effects of Selected Proteins on Iron Bioavailability. Am J Clin Nutr., 39, 393-401.

24. Simpson, K. M., Morris, E. R., \& Cook J. D. (1981). The inhibitory effect of iron absorption in man. Am J Clin Nutr., 34, 1468-1478.

25. Cook, J. D., Dassenko, S. A., \& Whitteker, P. (1991). Calcium supplemention: effecton iron absorption. Am. J. Clin Nut., 53, 106-111.

26. Rossander, L. (1987). Effecet of dietary fiber on iron absorbtion in man. Scan $J$ Gastroenterol (Suppl), 129, 68-72.

27. Pişkin, Ö. (2017). Demir Eksikliği ve Anemisi. AM Demir, B Ündar, Ş Ünal (ed). Hematolog. Ankara: Türk Hematoloji Derneği.

28. Özdemir, N. (2015). Çocuklarda demir eksikliği anemisi, Türk Pediatri Arşivi.

29. Koç, A., Karakaş. Z., Karaman. S., \& Karapınar, T. H. (Kasım 2014). Çocuk hastalıklarında tanı ve tedavi klavuzu, Türkiye Milli Pediatri Derneği ile Türk Pediatrik Hematoloji Derneği Ortak Klavuzu, 13-19.

30. World Health Organization. The prevalance of anemia in women: a tabulation of available information. 2nd ed. Genevre 1992.

31. Atamer, T. (Eylül 2005). Akut Anemili Hastaya Klinik Yaklaşım. VII. Ulusal İç Hastalıkları Kongresi, İstanbul

32. Sağlık

Bakanlığı.

2013. http://istanbulsaglik.gov.tr/w/anasayfalinkler/belge/bakanlikistatistik/istatistik2013.pdf ) (Erişim Tarihi: 25 Kasım 2017)

33. Kuku, İ. (Ekim 2009) Sağlık Demir Eksikliğinde Güncel Durum. İnönü Üniversitesi Tıp Fakültesi XXXV. Ulusal Hematoloji Kongresi, Antalya

34. Özdemir, Ö., Can Çalışkan, S., Semizel, E., \& Okan, M. S. (2009). Katılma Nöbetli Hastaların Klinik ve Laboratuvar Bulguları. Türk Pediatri Arşivi, 7: 68-75. http://www.guncelpediatri.com/makale 791/Katilma-Nobetli-Hastalarin-Klinik-VeLaboratuvar-Bulgulari-Ozgun-Arastirma) (Erişim Tarihi: 21 Aralık 2017)

35. Akdemir, N., \& Birol, L. (2015). Iç hastalıkları ve hemşirelik bakımı. Ankara: Sistem Ofset

36. Türk Hematoloji Derneği. Çocuklarda demir eksikliği anemisi tanı ve tedavi klavuzu 2011. file:///E:/türk\%20hematooji\%20derneği.pdf (Erişim Tarihi: 08 Kasım 2017)

37. Türk Hematoloji Derneği. Eritrosit hastalıkları ve hemoglobin bozuklukları tanı ve tedavi http:www.thd.org.tr/Search.aspx?q=tan\%c4\%b1+ve+tedavi+klavuzu\&cx=0029127486 $\underline{35621247780 \% 3 a y g n y e f y y s f a \& c o f=F O R I D \% 3 a 11 ~(E r i s ̧ i m ~ T a r i h i: ~} 30$ Ağustos 2018) 